\title{
Response of Growth and Yield of Basil (Ocimum Sanctum L.) to Several Concentrations of Liquid Organic Fertilizers and Growth Regulators
}

\section{Respon Pertumbuhan dan Hasil Tanaman Kemangi (Ocimum Sanctum L.) Terhadap Beberapa Konsentrasi Pupuk Organik Cair dan Zat Pengatur Tumbuh}

\author{
Rio Hasten, Palupi Puspitorini, Tri Kurniastuti* \\ \{riohasten2@gmail.com, puspitorini.palupi@gmail.com, kurniastuti5@gmail.com*\}
}

Program Studi Agroteknologi, Fakultas Pertanian, Universitas Islam Balitar, Blitar, Indonesia

\begin{abstract}
This research was conducted to determine the interaction of combination treatment of liquid organic ferilizer and growth regulators with different concentrations on the growth and yield of basil plants (Ocimum sanctum L.). The research was carried out in March-May 2021 in Doko village, Blitar. The treatments were arranged in a factorial randomized block design (RAK Faktorial). The treatments in this study included 2 factors which were repeated 3 times. The first factor is the application of liquid organic fertilizer which consists of 3 levels, namely 0 (control), 5, and $10 \mathrm{ml} /$ /iter. The second factor is the application of growth regulators which consists of 3 levels, namely 3, 6, and $9 \mathrm{ml} /$ liter. The variables observed included plant height, number of eaves, number of branches, and fresh weight. The results of the analysis of variance showed that there was a significant effect on the combination of dosages of liquid organic fertilizer and growth regulators on all observation variables, namely plant height, number of leaves, number of branches, and fresh weight. The best treatment combination is shown by the application of liquid organic fertilizer $10 \mathrm{ml} /$ /iter and growth regulators $9 \mathrm{ml} / \mathrm{liter}$.
\end{abstract}

Keywords - ocimum sanctum; growth regulators; liquid organic fertilizer

Abstrak. Penelitian ini dilakukan untuk mengetahui interaksi kombinasi perlakuan pupuk organik cair dan zat pengatur tumbuh dengan konsentrasi yang berbeda terhadap pertumbuhan dan hasil tanaman kemangi (Ocimum sanctum L.). Penelitian dilaksanakan pada bulan Maret-Mei 2021 di Desa Doko, Kecamatan Doko, Kabupaten Blitar. Perlakuan disusun dalam Rancangan Acak Kelompok Faktorial (RAK Faktorial). Perlakuan pada penelitian ini meliputi 2 faktor yang di ulangi 3 kali. Faktor pertama yaitu pemberian pupuk organik cair yang terdiri dari 3 level yaitu 0 (control), 5, dan $10 \mathrm{ml} /$ liter. Faktor kedua yaitu pemberian ZPT yaitu 3, 6, dan 9 ml/liter. Variabel yang diamati meliputi tinggi tanaman, jumlah daun, jumlah cabang, dan bobot segar. Hasil analisis ragam menunjukkan terdapat pengaruh yang nyata pada kombinasi perlakuan dosis pupuk organik cair dan zat pengatur tumbuh pada semua variabel pengamatan yaitu tinggi tanaman, jumlah daun, jumlah cabang, dan bobot segar. Kombinasi perlakuan terbaik ditunjukkan oleh pemberian pupuk organik cair 10 ml/liter dan zat pengatur tumbuh 9 $\mathrm{ml} /$ liter.

Kata Kunci- ocimum sanctum; zat pengatur tumbuh; pupuk organik cair,

\section{PENDAHULUAN}

Tanaman kemangi (Ocimum sanctum L.) merupakan tanaman yang tergolong hemafrodit dan tumbuh di daerah tropis, tanaman ini termasuk family lamiaceae dan banyak tumbuh di indonesia. Sejalan dengan peningkatan di bidang ilmu pengetahuan dan teknologi, masyarakat telah menggunakan tanaman kemangi sebagai tanaman yang memiliki nilai ekonomi tinggi, umumnya daun kemangi dijadikan sebagai penggenap masakan atau menjadi ulam oleh masyarakat [1].

Berdasarkan data Badan Pusat Statistik ( BPS ) RI 2013, jumlah Rumah Tangga Usaha Hortikultura Kemangi sebesar 12.675 dengan luas tanam yakni $7.334 .397 \mathrm{~m} 2$ dan rata-rata luas tanam yang diselenggarakan per rumah tangga sebesar $578 \mathrm{~m} 2$ [2].

Salah satu permasalahan yang sering muncul dalam budidaya kemangi adalah kurangnya pemberian nurisi. Pemberian pupuk merupakan salah satu faktor yang berpengaruh untuk budidaya tanaman. Pemberian pupuk akan memasok unsur hara yang dibutuhkan untuk reaksi pertumbuhan dan produksinya. Bentuk pupuk organik adalah padat dan cair. Kelebihan pupuk organik jenis cair adalah ketersediaan unsur hara dan cepatnya penyerapan oleh akar tanaman.

Salah satu jenis pupuk organik cair yang digunakan dalam budidaya pertanian adalah POC NASA. POC Nasa mempunyai kandungan unsur hara makro dan mikro, protein, lemak, asam-asam organik dan zat stimulus tumbuhan seperti Gibberelin, auksin, dan Sitokinin [3]. 
Selain pupuk, zat pengatur tumbuh ( ZPT ) juga dibutuhkan oleh tanaman, seperti salah satu label dagang yang dikenal adalah Hormon Organik. Hormon organik atau dikenal juga dengan istilah ZPT Hormonik yakni faktor pendukung dalam keberhasilan budidaya pertanian yang bisa memberikan kontribusi sacara besar.

Berdasarkan pada uraian di atas penulis melakukan penelitian perihal pertumbuhan dan hasil kemangi dengan beberapa konsentrasi pupuk organik cair dan ZPT yang berbeda-beda. Penelitian ini bertujuan untuk mengetahui respon pemberian pupuk organik cair dan ZPT dengan berbagai konsentrasi yang berbeda-beda serta ada tiadanya pengaruh interaksi antara kedua faktor tersebut.

\section{METODE}

Penelitian ini dilakukan di lahan yang terletak di desa Doko Kecamatan Doko Kabupaten Blitar, pada bulan 15 Maret sampai tanggal 19 Mei 2021. Lokasi berada pada ketinggian 324 mdpl.

Bahan -bahan yang digunakan dalam penelitian ini adalah : Benih kemangi, Pupuk Organik Cair NASA, ZPT Hormon Organik, Pupuk Petroganik dan NPK, Media tanam berupa tanah halus, pasir halus, pupuk kandang, dan Insektisida Peralatan yang digunakan dalam penelitian ini terdiri dari : Cangkul, parang, hand spayer, baki, penggaris, timbang digital, papan nama dan alat tulis lainnya yang mendukung penelitian ini.

Metode yang digunakan dalam penelitian ini adalah metode kuantitatif yang disusun dalam Rancangan Acak Kelompok Faktorial ( RAK Faktorial ). Perlakuan pada penelitian ini meliputi 2 faktor yang di ulangi 3 kali. Faktor pertama yaitu pemberian pupuk organik cair yang terdiri dari 3 level $(\mathrm{P} 1=$ tanpa $\mathrm{POC} / \mathrm{kontrol}, \mathrm{P} 2=5 \mathrm{ml} / \mathrm{liter}, \mathrm{P} 3=$ $10 \mathrm{ml} /$ liter ). Faktor kedua yaitu pemberian ZPT ( $\mathrm{H} 1=3 \mathrm{ml} / \mathrm{liter}, \mathrm{H} 2=6 \mathrm{ml} / \mathrm{liter}, \mathrm{H} 3=9 \mathrm{ml} / \mathrm{liter}$ ). Faktor kedua yaitu pemberian ZPT ( $\mathrm{H} 1=3 \mathrm{ml} /$ liter, $\mathrm{H} 2=6 \mathrm{ml} /$ liter, $\mathrm{H} 3=9 \mathrm{ml} /$ liter $)$. Sehingga terdapat 9 kombinasi perlakuan sebagai berikut : P1H1 = tanpa POC (kontrol) x ZPT $3 \mathrm{ml} /$ liter, P1H2 = tanpa POC (kontrol) $\times$ ZPT 6 ml/liter, P1H3 $=$ tanpa POC (kontrol) x ZPT $9 \mathrm{ml} /$ liter, P2H1 = POC $5 \mathrm{ml} /$ liter $\times \mathrm{ZPT} 3 \mathrm{ml} /$ liter, P2H2 = POC $5 \mathrm{ml} /$ liter $\times$ ZPT 6 $\mathrm{ml} /$ liter, P2H3 = POC $5 \mathrm{ml} /$ liter $\times \mathrm{ZPT} 9 \mathrm{ml} / \mathrm{liter}$, P3H1 = POC $10 \mathrm{ml} / \mathrm{liter} \times \mathrm{ZPT} 3 \mathrm{ml} / \mathrm{liter}$, P3H2 = POC 10 $\mathrm{ml} /$ liter $\times$ ZPT $6 \mathrm{ml} /$ liter, P3H3 = POC $10 \mathrm{ml} /$ liter x ZPT 9 ml/liter. Parameter yang diamati adalah tinggi tanaman ( $\mathrm{cm}$ ), jumlah daun, jumlah cabang, dan bobot segar ( $\mathrm{gr}$ ).

\section{A. Tinggi tanaman (cm)}

\section{HASIL DAN PEMBAHASAN}

Tabel 1. Rata-rata Pemberian Pupuk Organik Cair dan Zat Pengatur Tumbuh Terhadap Tinggi Tanaman Kemangi Pada Umur 10, 17, 24, 31, 38 HST.

\begin{tabular}{cccccc}
\hline PERLAKUAN & \multicolumn{5}{c}{ RATA-RATA TINGGI TANAMAN ( CM ) PER HST } \\
\cline { 2 - 6 } & $\mathbf{1 0}$ & $\mathbf{1 7}$ & $\mathbf{2 4}$ & $\mathbf{3 1}$ & $\mathbf{3 8}$ \\
P1H1 & $4,92 \mathrm{ab}$ & $11,67 \mathrm{ab}$ & $27,69 \mathrm{~b}$ & $39,04 \mathrm{bc}$ & $54,77 \mathrm{~b}$ \\
P1H2 & $5,23 \mathrm{bcd}$ & $11,74 \mathrm{ab}$ & $26,64 \mathrm{a}$ & $38,81 \mathrm{bc}$ & $54,12 \mathrm{ab}$ \\
P1H3 & $5,24 \mathrm{bcd}$ & $11,37 \mathrm{a}$ & $27,06 \mathrm{ab}$ & $36,98 \mathrm{a}$ & $52,92 \mathrm{a}$ \\
P2H1 & $5,53 \mathrm{bcd}$ & $12,71 \mathrm{~b}$ & $27,6 \mathrm{~b}$ & $39,59 \mathrm{c}$ & $55,07 \mathrm{~b}$ \\
P2H2 & $5,07 \mathrm{abc}$ & $11,79 \mathrm{ab}$ & $27,39 \mathrm{ab}$ & $39,98 \mathrm{c}$ & $55,2 \mathrm{~b}$ \\
P2H3 & $5,32 \mathrm{bcd}$ & $11,76 \mathrm{ab}$ & $27,36 \mathrm{ab}$ & $37,64 \mathrm{ab}$ & $53,83 \mathrm{ab}$ \\
P3H1 & $5,57 \mathrm{~cd}$ & $12,06 \mathrm{ab}$ & $27,67 \mathrm{~b}$ & $39,12 \mathrm{bc}$ & $55,11 \mathrm{~b}$ \\
P3H2 & $4,6 \mathrm{a}$ & $11,72 \mathrm{ab}$ & $27,72 \mathrm{~b}$ & $37,88 \mathrm{ab}$ & $53,18 \mathrm{ab}$ \\
P3H3 & $5,78 \mathrm{~d}$ & $13,44 \mathrm{c}$ & $29,14 \mathrm{c}$ & $38,91 \mathrm{bc}$ & $55,04 \mathrm{~b}$ \\
BNJ 5\% & 0,63 & 1,16 & 0,95 & 1,53 & 1,44 \\
\hline
\end{tabular}

Keterangan : Angka yang diikuti huruf pada kolom menunjukkan berbeda nyata pada uji BNJ dengan taraf kesalahan 5\%.

HST : Hari Setelah Tanam; P : pupuk; H : ZPT

\section{B. Jumlah daun}


Procedia of Engineering and Life Science Vol. 2. No. 1 October 2021

Seminar Nasional \& Call Paper Fakultas Sains dan Teknologi (SENASAINS $3^{\text {rd }}$ )

Universitas Muhammadiyah Sidoarjo

Tabel 2. Rata-Rata Pemberian Pupuk Organik Cair dan Zat Pengatur Tumbuh Terhadap Jumlah Daun Tanaman Kemangi Pada Umur 10, 17, 24, 31, 38 HST.

\begin{tabular}{cccccc}
\hline PERLAKUAN & \multicolumn{5}{c}{ RATA-RATA JUMLAH DAUN PER HST } \\
\cline { 2 - 6 } P1H1 & $\mathbf{1 0}$ & $\mathbf{1 7}$ & $\mathbf{2 4}$ & $\mathbf{3 1}$ & $\mathbf{3 8}$ \\
P1H2 & $7,11 \mathrm{bc}$ & $14 \mathrm{~b}$ & $46,78 \mathrm{abc}$ & $73,67 \mathrm{abc}$ & $108,56 \mathrm{a}$ \\
P1H3 & $6,56 \mathrm{ab}$ & $14,11 \mathrm{~b}$ & $45,89 \mathrm{a}$ & $72 \mathrm{a}$ & $110,56 \mathrm{ab}$ \\
P2H1 & $7 \mathrm{bc}$ & $13,67 \mathrm{~b}$ & $50,89 \mathrm{~d}$ & $73,44 \mathrm{abc}$ & $113,11 \mathrm{~b}$ \\
P2H2 & $7,67 \mathrm{c}$ & $15,11 \mathrm{~b}$ & $51 \mathrm{~d}$ & $75,22 \mathrm{c}$ & $111,67 \mathrm{ab}$ \\
P2H3 & $7,22 \mathrm{bc}$ & $14,44 \mathrm{~b}$ & $49,78 \mathrm{bcd}$ & $73,89 \mathrm{bc}$ & $113,11 \mathrm{~b}$ \\
P3H1 & $6,67 \mathrm{ab}$ & $14,78 \mathrm{~b}$ & $47,33 \mathrm{abc}$ & $72,11 \mathrm{ab}$ & $112 \mathrm{ab}$ \\
P3H2 & $7,33 \mathrm{bc}$ & $15,11 \mathrm{~b}$ & $50,44 \mathrm{~cd}$ & $73,89 \mathrm{bc}$ & $113,33 \mathrm{~b}$ \\
P3H3 & $5,89 \mathrm{a}$ & $11,22 \mathrm{a}$ & $46,22 \mathrm{ab}$ & $73 \mathrm{ab}$ & $108 \mathrm{a}$ \\
BNJ 5\% & $7,22 \mathrm{bc}$ & $14,56 \mathrm{~b}$ & $49,22 \mathrm{abc}$ & $72,89 \mathrm{ab}$ & $108,78 \mathrm{a}$ \\
\hline
\end{tabular}

Keterangan : Angka yang diikuti huruf pada kolom menunjukkan berbeda nyata pada uji BNJ dengan taraf kesalahan $5 \%$.

HST : Hari Setelah Tanam; P : pupuk; H : ZPT

\section{Jumlah cabang}

Tabel 3. Rata-Rata Pemberian Pupuk Organik Cair dan Zat Pengatur Tumbuh Terhadap Jumlah Cabang Tanaman Kemangi Pada Umur 10, 17, 24, 31, 38 HST.

\begin{tabular}{|c|c|c|c|c|c|}
\hline \multirow[t]{2}{*}{ PERLAKUAN } & \multicolumn{5}{|c|}{ RATA-RATA JUMLAH CABANG PER HST } \\
\hline & $\mathbf{1 0}$ & 17 & 24 & 31 & 38 \\
\hline P1H1 & 0 & $4,22 \mathrm{abc}$ & $8,56 \mathrm{ab}$ & $11,11 \mathrm{ab}$ & $12,44 \mathrm{a}$ \\
\hline P1H2 & 0 & $5,11 \mathrm{bc}$ & $8,56 a b$ & $10,89 \mathrm{ab}$ & $12,56 \mathrm{ab}$ \\
\hline P1H3 & 0 & $4 \mathrm{ab}$ & $8 \mathrm{a}$ & $10,44 \mathrm{a}$ & $13,44 \mathrm{~cd}$ \\
\hline P2H1 & 0 & $3,78 \mathrm{a}$ & $8,78 \mathrm{abc}$ & $10,56 \mathrm{a}$ & $13,56 \mathrm{~d}$ \\
\hline Р2H2 & 0 & $4,67 \mathrm{abc}$ & 9,44 bc & $11,33 \mathrm{ab}$ & $13,44 \mathrm{~cd}$ \\
\hline Р2H3 & 0 & $4,89 \mathrm{abc}$ & $9,67 \mathrm{c}$ & $11,33 \mathrm{ab}$ & $13,11 \mathrm{abcd}$ \\
\hline P3H1 & 0 & $4,78 \mathrm{abc}$ & $8,67 \mathrm{ab}$ & $11,33 \mathrm{ab}$ & $13,33 \mathrm{bcd}$ \\
\hline P3H2 & 0 & $3,89 \mathrm{a}$ & $8,33 \mathrm{ab}$ & $10,78 \mathrm{ab}$ & $12,67 \mathrm{abc}$ \\
\hline P3H3 & 0 & $5,22 \mathrm{c}$ & 9,44 bc & $11,78 \mathrm{~b}$ & $13,89 \mathrm{~d}$ \\
\hline BNJ 5\% & 0 & 1,14 & 0,96 & 1 & 0,79 \\
\hline
\end{tabular}

Keterangan : Angka yang diikuti huruf pada kolom menunjukkan berbeda nyata pada uji BNJ dengan taraf kesalahan $5 \%$.

HST : Hari Setelah Tanam; P : pupuk; H : ZPT

\section{Bobot segar ( gr )}

Tabel 4. Bobot Segar Tanaman Kemangi ( gr )

\begin{tabular}{cc}
\hline PERLAKUAN & BOBOT SEGAR ( gr \\
\hline P1H1
\end{tabular}


Procedia of Engineering and Life Science Vol. 2. No. 1 October 2021

Seminar Nasional \& Call Paper Fakultas Sains dan Teknologi (SENASAINS 3rd)

Universitas Muhammadiyah Sidoarjo

\begin{tabular}{cc}
$\mathrm{P} 2 \mathrm{H} 1$ & $35,28 \mathrm{~b}$ \\
$\mathrm{P} 2 \mathrm{H} 2$ & $35,1 \mathrm{~b}$ \\
$\mathrm{P} 2 \mathrm{H} 3$ & $35,09 \mathrm{~b}$ \\
$\mathrm{P} 3 \mathrm{H} 1$ & $34,70 \mathrm{~b}$ \\
$\mathrm{P} 3 \mathrm{H} 2$ & $35,2 \mathrm{~b}$ \\
$\mathrm{P} 3 \mathrm{H} 3$ & $35,65 \mathrm{~b}$ \\
BNJ 5\% & 0,96 \\
\hline
\end{tabular}

Keterangan : Angka yang diikuti huruf pada kolom menunjukkan berbeda nyata pada uji BNJ dengan taraf kesalahan $5 \%$.

$\mathrm{P}:$ pupuk; H : ZPT

\section{E. Interaksi Kombinasi Perlakuan Pupuk Organik Cair dan ZPT}

\section{Tinggi tanaman}

Dari hasil analisis ragam (Tabel 1) dapat disimpulkan bahwa dari perlakuan pemberian pupuk organik cair dan zat pengatur tumbuh terhadap hasil rataan tinggi tanaman tertinggi ditunjukkan oleh kombinasi perlakuan P3H3 ( pupuk organik cair $10 \mathrm{ml} /$ liter dan zat pengatur tumbuh $9 \mathrm{ml} /$ liter ). Hal ini diduga karena pupuk organik cair dan zat pengatur dengan konsentrasi tertentu memberikan unsur hara kepada tanaman dengan jumlah yang cukup.

Reo (1994) menyatakan terdapat beberapa unsur penting yang terkandung didalam pupuk organik cair dalam sistem metabolisme tanaman yaitu sintesis asam amino dan ion-ion ammonium, yang memiliki tugas untuk memelihara secara baik tekanan turgor tanaman, memungkinkan proses metabolisme berjalan dengan lancar dan proses kelangsungan perpanjangan sel menjadi terjamin sehingga pertumbuhan panjang tanaman menjadi cepat. Unsur lainnya yang memiliki peranan penting bagi pertumbuhan tanaman tidak hanya bersumber dari pupuk organik cair tetapi juga hasil kinerja zat pengatur tumbuh ( ZPT ) [4]. Dalam penelitian Neli. S, dkk. ( 2016 ), perlakuan pemberian POC Nasa dengan berbagai konsentrasi mampu dapat direspon dengan cepat oleh tanaman, terutama masa pertumbuhan vegetatif, yaitu tinggi tanaman. Sedangkan pengaplikasian zat pengatur tumbuh dapat memacu penyerapan unsur hara mikro yang terkandung pada POC Nasa yang diaplikasikan untuk merangsang pertumbuhan vegetatif tanaman. Tersedianya unsur hara yang dibutuhkan tanaman tentunya berpengaruh terutama di masa pertumbuhan vegetatif, karena masa vegetatif adalah masa pembentukan dan perkembangan akar, batang, cabang, dan daun pada tanaman. Hal ini sejalan dengan pendapat Dwi Putri, dkk. ( 2017 ) yang menyatakan bahwa tinggi tanaman yang mengalami pertambahan saat masa vegetatif cenderung sangat tinggi apabila dibandingkan dengan masa generatif. Hal ini disebabkan suplai nitrogen di masa vegetatif terfokus pada pertumbuhan pucuk atau apikal, sedangkan pada masa generatif pertumbuhannya lebih banyak pada munculnya bunga dibandingkan pertambahan tinggi tanaman [5].

\section{Jumlah daun}

Dari hasil analisis ragam ( Tabel 2 ) dapat disimpulkan bahwa dari perlakuan pemberian pupuk organik cair dan zat pengatur tumbuh terhadap hasil rataan jumlah daun tertinggi ditunjukkan oleh kombinasi perlakuan P2H1 ( pupuk organik cair $5 \mathrm{ml} /$ liter dan zat pengatur tumbuh $3 \mathrm{ml} /$ liter ). Hal ini diduga nutrisi yang didapat dari konsentrasi perlakuan pupuk organik cair dan zat pengatur tumbuh telah mencukupi sehingga perkembangan vegetatif tanaman menjadi baik. Dalam penelitian Supriyanto, B. ( 2013 ) menduga bahwa pengaplikasian ZPT dan pengaplikasian POC dengan konsentrasi yang sesuai akan berpengaruh terhadap pertambahan jumlah daun dengan memberikan hasil yang lebih besar, maka dari itu pengaplikasian larutan ZPT dan POC disesuaikan dengan konsentrasi dan memperhatikan keseimbangan supaya tepat. Dengan banyaknya jumlah daun yang tumbuh, maka akan memperbesar peluang tanaman untuk menangkap sinar matahari yang digunakan sebagai salah satu bahan untuk jalannya proses fotosintesis dimana hasil fotosintesisnya akan dimanfaatkan selama masa pertumbuhan tanaman itu berlangsung [6]. Hal ini sejalan dengan pendapat Tisdale ( 2003 ) dalam Nasution, Y.R. ( 2019 ) yang menyatakan hasil fotosintesis berupa karbohidrat atau yang biasa disebut fotosintat akan digunakan tanaman untuk proses pembelahan sel tanaman, sehingga perkembangan tinggi tanaman, jumlah daun, dan luas daun tanaman dapat terpacu [7].

\section{Jumlah cabang}

Dari hasil analisis ragam ( Tabel 3 ) dapat disimpulkan bahwa dari perlakuan pemberian pupuk organik cair dan zat pengatur tumbuh terhadap hasil rataan jumlah cabang tertinggi ditunjukkan oleh kombinasi perlakuan P3H3 ( pupuk organik cair $10 \mathrm{ml} /$ liter dan zat pengatur tumbuh $9 \mathrm{ml} /$ liter ). Hal ini diduga unsur hara yang didapat dari konsentrasi perlakuan pupuk organik cair dan zat pengatur tumbuh mencukupi dan mendukung pertumbuhan 
vegetatif tanaman menjadi optimal. Leiwakabessy ( 1977 ) dalam Fitra, Y. ( 2013 ) berpendapat bahwa ketersediaan unsur hara sangat mempengaruhi pertumbuhan dan perkembangan suatu tanaman, karena dapat memacu proses metabolisme dan pembentukan sel pertumbuhan jika unsur hara yang berada di dalam jaringan tanaman memiliki keadaan yang optimal. Proses metabolisme pada jaringan tanaman akan terpengaruh apabila ketersediaan unsur hara dalam jumlah yang cukup dan seimbang [8]. Dalam penelitian Antono, Y. dan Yulia, A. ( 2018 ) menyatakan dengan terbentuknya cabang dalam jumlah yang banyak, maka produksi jumlah daun akan mengalami peningkatan sehingga proses fotosintesis akan semakin optimal. Dengan optimalnya proses fotosintesis, maka fotosintat yang dihasilkan juga akan optimal untuk dimanfaatkan selama masa pertumbuhan dan perkembangan [9].

Bobot segar

Dari tabel analisis ragam (Tabel 4) dapat disimpulkan bahwa hasil terbaik dari perlakuan pemberian pupuk organik cair dan zat pengatur tumbuh terhadap hasil bobot segar ditunjukkan pada kombinasi perlakuan P3H3 ( pupuk organik cair $10 \mathrm{ml} /$ liter dan zat pengatur tumbuh $9 \mathrm{ml} / \mathrm{liter}$ ) hal ini diduga nutrisi yang didapat dari konsentrasi perlakuan pupuk organik cair dan zat pengatur tumbuh mencukupi selama masa pertumbuhan vegetatif ( pembentukan akar, batang, daun, dan bagian yang lain ) sehingga menyebabkan berat basahnya semakin banyak. Dalam penelitian Pramita, dkk. (2018) dijelaskan bahwa untuk mendapatkan hasil yang optimal perlu menggunakan perlakuan interaksi dosis terbanyak karena menghasilkan bobot segar yang paling tinggi di antara interaksi yang lain. Penambahan hormon dengan dosis tertinggi sebagai hormon eksogen pada tanaman akan mengakibatkan kandungan hormon didalam tubuh tanaman ( tajuk ) menjadi meningkat [10].

\section{F. Respon pemberian konsentrasi pupuk organik cair}

Tabel 5. Rata-Rata tinggi tanaman, jumlah daun, jumlah cabang, dan bobot segar terhadap berbagai konsentrasi pupuk organik cair

\begin{tabular}{ccccc}
\hline Variabel yang diamati & \multicolumn{2}{c}{ Konsentrasi POC $(\mathbf{~ m l} / \mathbf{l}$ air $)$} & BNJ 0,05 \\
\cline { 2 - 3 } Tinggi Tanaman umur 10 HST $(\mathrm{cm})$ & Kontrol & 5 & 10 & - \\
Tinggi Tanaman umur 17 HST $(\mathrm{cm})$ & 5,13 & 5,31 & 5,32 & - \\
Tinggi Tanaman umur 24 HST $(\mathrm{cm})$ & 11,59 & 12,09 & 12,41 & 0,95 \\
Tinggi Tanaman umur 31 HST $(\mathrm{cm})$ & $27,13 \mathrm{a}$ & $27,45 \mathrm{ab}$ & $28,18 \mathrm{~b}$ & - \\
Tinggi Tanaman umur 38 HST ( cm $)$ & 38,28 & 39,07 & 38,64 & - \\
Jumlah Daun umur 10 HST & 53,94 & 54,70 & 54,44 & - \\
Jumlah Daun umur 17 HST & 6,96 & 7,18 & 6,74 & - \\
Jumlah Daun umur 24 HST & 13,93 & 14,78 & 13,63 & - \\
Jumlah Daun umur 31 HST & 47,85 & 49,37 & 48,62 & - \\
Jumlah Daun umur 38 HST & 73,03 & 73,74 & 73,26 & - \\
Jumlah Cabang umur 10 HST & 110,74 & 112,26 & 110,04 & - \\
Jumlah Cabang umur 17 HST & 0 & 0 & 0 & - \\
Jumlah Cabang umur 24 HST & 4,44 & 4,44 & 4,63 & - \\
Jumlah Cabang umur 31 HST & 8,44 & 9,22 & 8,81 & 0,96 \\
Jumlah Cabang umur 38 HST & 10,81 & 11,07 & 11,30 & - \\
Bobot segar ( gr ) & $12,81 \mathrm{a}$ & $13,37 \mathrm{a}$ & $13,30 \mathrm{a}$ & 0,79 \\
\hline
\end{tabular}

Dari tabel 5 menunjukkan pada variabel tinggi tanaman pada kemangi lebih baik dijumpai pada konsentrasi pupuk organik cair $10 \mathrm{ml} /$ liter ( P3 ) yang tidak berbeda nyata dengan konsentrasi pupuk organik cair $5 \mathrm{ml} / \mathrm{liter}$ ( P2 ) namun berbeda nyata terhadap tanpa konsentrasi pupuk organik cair ( P1 ). Hal ini diduga karena pada konsentrasi tersebut unsur hara yang dibutuhkan oleh tanaman kemangi tercukupi dan seimbang di dalam POC, sehingga mempengaruhi pertumbuhan menjadi lebih baik. Wibawa ( 1998 ) dalam Asnijar, dkk. ( 2013 ) menyatakan untuk mendapatkan pertumbuhan tanaman yang baik maka unsur hara yang di butuhkan tanaman harus dalam bentuk seimbang, tersedia, dan optimum, dan didukung oleh faktor lingkungannya. Pada variabel jumlah cabang kemangi ditemukan bahwa konsentrasi pupuk organik cair $10 \mathrm{ml} /$ liter ( P3 ) tidak berbeda nyata dengan konsentrasi pupuk organik cair $5 \mathrm{ml} /$ liter ( P2 ) dan tanpa konsentrasi pupuk organik cair ( P1 ). Hal ini diduga pupuk organik cair tidak begitu merangsang pembentukan cabang dan hanya mempengaruhi tinggi tanaman.

\section{G. Respon pemberian konsentrasi zat pengatur tumbuh}

Tabel 6. Rata-Rata tinggi tanaman, jumlah daun, jumlah cabang, dan bobot segar terhadap berbagai konsentrasi zat pengatur tumbuh 
Procedia of Engineering and Life Science Vol. 2. No. 1 October 2021

Seminar Nasional \& Call Paper Fakultas Sains dan Teknologi (SENASAINS $3^{\text {rd) }}$

Universitas Muhammadiyah Sidoarjo

\begin{tabular}{|c|c|c|c|c|}
\hline \multirow[t]{2}{*}{ Variabel yang diamati } & \multicolumn{3}{|c|}{ Konsentrasi ZPT ( ml / l air ) } & \multirow[t]{2}{*}{ BNJ 0,05 } \\
\hline & 3 & 6 & 9 & \\
\hline Tinggi Tanaman umur 10 HST ( $\mathrm{cm}$ ) & $5,34 \mathrm{a}$ & $4,97 \mathrm{a}$ & $5,45 \mathrm{a}$ & 0,63 \\
\hline Tinggi Tanaman umur 17 HST ( $\mathrm{cm}$ ) & 12,14 & 11,75 & 12,19 & - \\
\hline Tinggi Tanaman umur 24 HST $(\mathrm{cm})$ & 27,65 & 27,25 & 27,85 & - \\
\hline Tinggi Tanaman umur 31 HST $(\mathrm{cm}$ ) & $39,25 \mathrm{a}$ & $38,89 \mathrm{a}$ & $37,84 \mathrm{a}$ & 1,53 \\
\hline Tinggi Tanaman umur 38 HST $(\mathrm{cm})$ & $54,98 \mathrm{a}$ & $54,17 \mathrm{a}$ & $53,93 a$ & 1,44 \\
\hline Jumlah Daun umur 10 HST & $7,37 \mathrm{~b}$ & $6,56 a$ & $6,96 \mathrm{ab}$ & 0,78 \\
\hline Jumlah Daun umur 17 HST & $14,74 \mathrm{a}$ & $13,26 \mathrm{a}$ & $14,33 \mathrm{a}$ & 1,96 \\
\hline Jumlah Daun umur 24 HST & 49,41 & 47,30 & 49,15 & - \\
\hline Jumlah Daun umur 31 HST & 73,96 & 73,26 & 72,81 & - \\
\hline Jumlah Daun umur 38 HST & 111,19 & 110,56 & 111,30 & - \\
\hline Jumlah Cabang umur 10 HST & 0,00 & 0,00 & 0,00 & - \\
\hline Jumlah Cabang umur 17 HST & 4,26 & 4,56 & 4,70 & - \\
\hline Jumlah Cabang umur 24 HST & 8,59 & 8,85 & 9,04 & - \\
\hline Jumlah Cabang umur 31 HST & 11,00 & 11,00 & 11,19 & - \\
\hline Jumlah Cabang umur 38 HST & $13,11 \mathrm{a}$ & $12,89 \mathrm{a}$ & $13,48 \mathrm{a}$ & 0,79 \\
\hline Bobot segar $(\mathrm{gr})$ & 35,06 & 35,02 & 34,87 & - \\
\hline
\end{tabular}

Dari tabel 6 menunjukkan pada variabel tinggi tanaman pada kemangi dijumpai pada konsentrasi zat pengatur tumbuh $9 \mathrm{ml} /$ liter ( $\mathrm{H} 3$ ) yang tidak berbeda nyata dengan zat pengatur tumbuh $6 \mathrm{ml} / \mathrm{liter}$ ( $\mathrm{H} 2$ ) dan zat pengatur tumbuh $3 \mathrm{ml} /$ liter ( $\mathrm{H} 1$ ). Hal ini diduga karena zat pengatur tumbuh kurang mendorong pertumbuhan tanaman dalam hal ini adalah pemanjangan batang. Pada variabel jumlah daun kemangi ditemukan bahwa konsentrasi zat pengatur tumbuh $3 \mathrm{ml} /$ liter ( $\mathrm{H} 1$ ) yang tidak berbeda nyata dengan zat pengatur tumbuh $9 \mathrm{ml} / \mathrm{liter}$ ( $\mathrm{H} 3$ ) namun berbeda nyata dengan zat pengatur tumbuh $6 \mathrm{ml} /$ liter ( $\mathrm{H} 2$ ). Hal ini diduga zat pengatur tumbuh dengan konsentrasi tertentu dapat memacu pertumbuhan tanaman dalam hal ini adalah pembentukan daun. Pada variabel jumlah cabang kemangi ditemukan bahwa konsentrasi zat pengatur tumbuh $9 \mathrm{ml} /$ liter ( $\mathrm{H} 3$ ) yang tidak berbeda nyata dengan zat pengatur tumbuh $6 \mathrm{ml} /$ liter ( $\mathrm{H} 2$ ) dan zat pengatur tumbuh $3 \mathrm{ml} /$ liter ( H1 ). Hal ini diduga hormon yang terdapat di dalam zat pengatur tumbuh tidak begitu merangsang pembentukan cabang dan hanya mempengaruhi tinggi tanaman.

\section{KESIMPULAN}

Terdapat interaksi perlakuan pupuk organik cair dan zat pengatur tumbuh pada variabel tinggi tanaman, jumlah daun, jumlah cabang, dan bobot segar. Kombinasi perlakuan terbaik ditunjukkan oleh P3H3 (pupuk organik cair 10 $\mathrm{ml} /$ liter dan zat pengatur tumbuh $9 \mathrm{ml} /$ liter) yang tidak berbeda nyata dengan $\mathrm{P} 1 \mathrm{H} 1, \mathrm{P} 1 \mathrm{H} 2, \mathrm{P} 2 \mathrm{H} 1, \mathrm{P} 2 \mathrm{H} 2$, $\mathrm{P} 2 \mathrm{H} 3$, dan $\mathrm{P} 3 \mathrm{H} 1$. Perlakuan pupuk organik cair dengan konsentrasi $10 \mathrm{ml} /$ liter merupakan perlakuan terbaik pada variabel tinggi tanaman dan jumlah cabang. Perlakuan zat pengatur tumbuh dengan konsentrasi 9 ml/liter merupakan perlakuan terbaik pada variabel tinggi tanaman, jumlah daun, dan jumlah cabang.

\section{REFERENSI}

[1] Safwan, Taufan, Sugara, and MK Rohmi, "Pengaruh Ekstrak Daun Kemangi ( Ocimum sanctum L. ) Terhadap Motilitas dan Konsentrasi Spermatozoa Mencit Jantan ( Mus musculus )," Jurnal Ilmiah Ibnu Sina, vol. I, no. 2, pp. 173-181, Oktober 2016.

[2] Nugrahani and Ratih, "Perbedaan Pertumbuhan dan Potensi Hasil 9 Jenis Tanaman Kemangi ( Ocimum basilicum L. )," Jurnal Produksi Tanaman, vol. VII, no. 10, pp. 1936-1942, Oktober 2019.

[3] Susana Neli, Noor Jannah, and Abdul Rahmi, "Pengaruh Pupuk Organik Cair Nasa dan Zat Pengatur Tumbuh Ratu Biogen Terhadap Pertumbuhan dan Hasil Tanaman Terung ( Solanum melongena L. ) Varietas Antaboga1," Jurnal Agrifor, vol. XV, no. 2, pp. 297-308, Oktober 2016.

[4] Fachiroh and Wahid, "Pengaruh Zat Pengatur Tumbuh ( ZPT ) dan Pupuk Organik Cair ( POC ) Keong mas ( Pamocea canaliculata L. ) terhadap Pertumbuhan dan Produksi Tanaman Sawi Hijau ( Brassica juncea L. )," Jurnal Nabatia, vol. IV, no. 2, 2016.

[5] DPO Damayanti, Tri Handoyo, and Slameto, "Pengaruh Ammonium (NH4+) dan Nitrat (NO3-) Terhadap Pertumbuhan dan Kandungan Minyak Atsiri Tanaman Kemangi ( Ocimum sanctum L. ) dengan Sistem 
Procedia of Engineering and Life Science Vol. 2. No. 1 October 2021

Seminar Nasional \& Call Paper Fakultas Sains dan Teknologi (SENASAINS 3rd)

Universitas Muhammadiyah Sidoarjo

Hidroponik," Jurnal Agritop, vol. XVI, no. 1, pp. 163-175, Juli 2018.

[6] B Supriyanto, "Aplikasi ZPT Novelgro Alpha dan POC Bio Sugih terhadap Pertumbuhan dan Bibit Adenium ( Adenium obesum var. Fadia )," Jurnal Agrifor, vol. XI, no. 2, 2012.

[7] YR Nasution, "Pengaruh Pemberian ZPT dan POC Urin Kelinci Meningkatkan Pertumbuhan Bibit Tanaman Karet ( Hevea brasiliensis Muell Arg ) Klon PB 260," Skripsi FP Unsu, 2019.

[8] Y Fitra, "Pengaruh Konsentrasi POC Nasa dan Pupuk Kandang Terhadap Pertumbuhan Serta Produksi Tanaman Cabai Merah," Skripsi FP Universitas Teuku Umar Aceh, 2013.

[9] Y Antono and A Yulia, "Pengaruh Konsentrasi dan Interval Pemberian Pupuk Organik Cair terhadap Pertumbuhan dan Produksi Tanaman Kacang Hijau ( Vigna radiata L. )," JOM Faperta, vol. V, no. 1, pp. 1-12, April 2018.

[10] Y.Pramita, NR.Wandasari, A.Salim, and A.Laksono, "Aplikasi Pupuk Organik dan Zat Pengatur Tumbuh dalam Peningkatan Produktivitas Tanah dan Tanaman," Semnas Prodi Agribisnis FP Unej, pp. 673-684, November 2018.

[11] Asnijar, E Kesumawati, and Syammiah, "Pengaruh Varietas dan Konsentrasi pupuk Bayfolan Tehadap Pertumbuhan dan Hasil Tanaman Cabai ( Capsicum annum L. )," Jurnal Agrista, vol. XVII, no. 2, pp. 60-66, 2013. 